\title{
Sensible determination of pile capacity by dynamic methods
}

Mark R. Svinkin MSCE, MSM, PhD

President, Vibraconsult, Cleveland, OH, USA (msvinkin@roadrunner.com)

Driven piles are the basis of reliable deep foundations broadly used for various types of buildings and structures. Static load tests are conducted to ascertain correct results of static analyses, but static load tests are expensive and timeconsuming procedures. Therefore, dynamic methods have become popular techniques for evaluation of the ultimate pile capacity. The results of dynamic methods strongly depend on hammer energy and soil conditions. Analyses of numerous case histories show good, bad and critical determination of pile capacity by dynamic methods. Verification of dynamic pile testing with a static load test does not always guarantee the pile's ability to withstand design loads. It is not reasonable to connect pile testing at any construction site with determination of the ultimate pile capacity because the major goal of pile testing at sites is verification of the pile capability to withstand design loads. It is necessary to verify experimentally the pile capacity to withstand the design load with an appropriate factor of safety and check the applicability of signal-matching software for specified sites. Dynamic methods provide a sensible and beneficial approach to verification of the pile capacity necessary for withstanding design loads applied to piles.

\section{Introduction}

Pile foundations are broadly used in industrial, transportation and civil construction. Correct determination of pile capacity is very important for the proper design, construction and cost of these foundations. It is common in design practice to calculate pile capacity by static analysis based on the results of in situ and laboratory soil and rock tests. Traditionally, the static load test (SLT) is used to determine the ultimate capacity of the pile-soil system or the value of a service load to be supported by a pile (Poulos and Davis, 1980). In recent decades, because of business and technical advantages in test implementation during pile driving and restrikes, dynamic methods have become an integral part of pile capacity determination in numerous construction projects.

High-strain dynamic pile testing (HSDPT) is based on the application of the stress-wave theory to piles and includes a signal-matching procedure for measured and computed force and velocity at the pile head. The first major developments of HSDPT methods and their results have been described in publications such as those of Goble and Rausche (1970), Rausche et al. (1985), Middendorp (1987) and Paquet (1988).

Similar instruments are used for dynamic measurements at the pile head, but there are various signal-matching techniques developed by different researchers. The three most popular signalmatching software programs, namely, Capwap, TNOWave and Simbat, were developed by GRL Engineers, Allnamics Pile Testing Expert (formerly TNO Building and Construction Research) and ESSI - Testconsult, respectively. These companies continue to improve hardware and software for the enhancement of the accuracy of pile capacity evaluation by dynamic methods.

It is necessary to underline that Rausche et al. (1985) stated that dynamic methods determine the pile capacity at the time of testing. Indeed, any in situ pile testing provides the pile capacity at the time of testing. which has nothing to do with prediction of pile capacity and has no connection with class A type prediction defined by Lambe (1973). Nevertheless, determination of pile capacity at various times after the end of driving (EOD) renders drawings of the pile capacities as a function of time after pile installation.

Dynamic methods include HSDPT, which uses short-duration impact loads for pile testing (Svinkin and Woods, 2009). According to Justason and Fellenius (2001), the Statnamic test (STN) is a long-duration impulsive test, but STN also belongs to dynamic methods.

Dynamic methods are commonly utilised for determination of pile capacity. These methods are a convenient tool in the pile driving industry, and they are applied for any piles in various soils. Although dynamic methods have been used in practice for years, the actual accuracy of dynamic methods is vague because of the different natures of dynamic and static tests; these differences have not been completely studied. The major goal of dynamic pile testing is determination of the ultimate pile capacity at the time of testing. The obtained results vary. It is possible to obtain good, bad and even critical results for similar soil conditions. Therefore, it is imperative to know what dynamic tests and software are appropriate for specified piles and soil conditions because dynamic methods are not adequate.

The application of dynamic methods has some potential problems and pitfalls, and SLTs have to be conducted to verify correct results of dynamic methods. A comparison of static and dynamic test results for general evaluation of dynamic methods is a complicated problem because results of dynamic methods depend on the pile properties, the soil conditions and soil set-up, the hammer energy and other factors. Also, there is no consensus regarding the definition of the failure load. Therefore, there is no complete clarity in verification of dynamic methods in comparison of their results 
with the failure loads. Moreover, determination of failure loads is beneficial information, but it is not the aim of dynamic pile testing. The major goal of dynamic methods is a proof of the pile capacity to withstand the design loads. The factor of safety (FS) approach is the proper approach to verification of pile capacities.

This paper examines the published results of dynamic and static load tests, demonstrates the variability of results of dynamic methods (mostly HSDPT) depending on various factors and analyses how to apply rationally the results of dynamic methods for verification of the required pile capacity.

\section{Overview of the problem}

Dynamic and static pile tests have different natures of applied forces and responses of pile-soil systems. Determination of pile capacity by HSDPT has major discrepancies in comparison with SLT and some uncertainties (Svinkin, 2004, 2010). These problems to a certain degree are inherent in all dynamic pile tests.

First, the long-term behaviour of the pile-soil system can be represented only approximately over short time dynamic pile testing. Second, measured force and velocity at the pile head are used for indirect determination of pile capacity with signal-matching software. Third, there are several failure criteria for determination of the ultimate pile capacity from SLT, and there is only the Davison limit for verification of pile capacity determined by HSDPT (Fellenius, 1980). Fourth, comparison of static and dynamic test results is a complicated problem because results of HSDPT depend on several various factors such as the hammer energy, the time between compared tests, the time after pile installation, the set-up rate, the sequence of tests, the pile type, the blow count, the type of signalmatching technique, the quality of dynamic records and the soil conditions. Published data often demonstrate comparison of SLT and HSDPT results without considering the factors mentioned earlier. Therefore, such comparisons are not the criteria for the acceptability of HSDPT results.

Also, there are other problems in dynamic pile testing that can strongly affect pile capacity determination by dynamic methods. These problems will be analysed further in this paper.

\section{Comparison of pile capacities determined by dynamic and static tests}

Two methods are used for comparison of static and dynamic pile test results. First, a comparison can be performed for individual piles. This approach is also used for finding pile capacities as a function of time after pile installation. Second, the ratio of pile capacities from restrikes to those from SLT is considered for various pile types and lengths, soil conditions and time intervals between comparable tests lumped together. Several examples of such comparisons made on the evidence of large databases are shown in the following sections.

\section{Likins et al. (1996)}

The authors proved the statistical correlation of restrike Capwap results with SLT. The original, automatic, best match and radiation damping Capwap results were compared with outcomes of SLT. The paper underlined the importance of using Capwap for restrikes and concluded that statistical correlations of Capwap restrike results clearly demonstrate the superiority of this method over other capacity determination methods (not prediction as written in the text) and emphasised the best Capwap determination of pile capacity from restrike tests conducted as long after pile installation as it is reasonably allowable.

Indeed, statistical analysis provides general assessment of comparative results of dynamic and static tests. However, a statistical approach cannot help increase the accuracy of determining the ultimate pile capacity at any specified construction site. Pile driving contractors must know the actual pile capacity at their construction sites, not the results of statistical assessment of Capwap determination of pile capacity in general.

It is necessary to say that Capwap was the first signal-matching technique developed for practical applications and substantial research was done for improvement of the pile-soil interaction model and software. It seems that dynamic testing with Capwap application is better presented in publications than dynamic testing with other similar software. The Capwap software is obviously the most popular in the pile driving industry. However, dynamic pile testing with Capwap has inherent features of dynamic methods, along with their problems, and it does not mean that dynamic testing with Capwap can replace SLT in determination of the ultimate pile capacity.

\section{Svinkin (2002)}

The data of 39 different piles driven in various soil conditions were taken for analyses from the Federal Highway Administration (FHWA)-GRL database. All chosen piles were dynamically and statically tested. The time differences between static and dynamic tests were 1-2 d, but the time elapsed after EOD was diverse. Dynamic records from restrike testing were available for all piles. A signal-matching technique - Capwap - was used for pile capacity determination from restrike data. For 27 piles, compared capacities had a good agreement within the acceptable margin of errors, but for 12 piles, capacities were calculated with worse results (Table 1).

The ultimate pile capacities were determined from SLT in accordance with the Davisson failure criterion, which provides a conservative value of pile capacity. The maximum value of pile capacity can be estimated with the Chin method, whose results are about 20 to $40 \%$ greater than the Davisson limit (Fellenius, 1980). Another approach is used by Briaud et al. (2000), who preferred the $D / 10$ criterion to the Davisson one because the $D / 10$ criterion yields a pile capacity about $40 \%$ higher. For foundation safety, computed pile capacities exceeding the Davisson limit by more than $20 \%$ were considered as overestimated values, which were not acceptable for pile foundation design. Underestimated pile capacities are good for foundation safety, but such capacities do not provide an economic design of pile foundations. 
Table 1. Results of static and dynamic pile tests

\begin{tabular}{|c|c|c|c|c|c|c|c|c|c|}
\hline \multicolumn{3}{|c|}{ Pile } & \multirow[b]{2}{*}{ Soil } & \multirow{2}{*}{$\begin{array}{c}\text { SLT pile } \\
\text { capacity: } \\
\text { kN }\end{array}$} & \multirow{2}{*}{$\begin{array}{c}\text { Time } \\
\text { between } \\
\text { EOD and } \\
\text { DT: } h\end{array}$} & \multirow{2}{*}{$\begin{array}{c}\text { Time } \\
\text { between } \\
\text { SLT and } \\
\text { DT: d }\end{array}$} & \multirow{2}{*}{$\begin{array}{c}\text { Blow } \\
\text { count: } \\
\text { blows/ } \\
0.3 \mathrm{~m}\end{array}$} & \multicolumn{2}{|c|}{ Capwap } \\
\hline Number & Description & Length: $\mathrm{m}$ & & & & & & $\begin{array}{c}\text { Pile } \\
\text { capacity: } \\
\text { kN }\end{array}$ & Error: \% \\
\hline 2(3) & $\begin{array}{c}610 \mathrm{~mm} \text { PSC } \\
305 \mathrm{~mm} \text { void } D\end{array}$ & $20 \cdot 20$ & $\begin{array}{c}\text { Sand and clay } \\
\text { HWT }\end{array}$ & 3160 & 12 & +24 & 240 & 2216 & -30 \\
\hline 7(48) & $\begin{array}{c}762 \mathrm{~mm} \text { PSC } \\
457 \mathrm{~mm} \text { void } D\end{array}$ & $31 \cdot 10$ & $\begin{array}{l}\text { Sand } \\
\text { HWT }\end{array}$ & 6635 & 31 & +48 & 432 & 3836 & -42 \\
\hline $10(51)$ & $\begin{array}{c}762 \mathrm{~mm} \text { PSC } \\
457 \mathrm{~mm} \text { void } D\end{array}$ & $30 \cdot 02$ & $\begin{array}{l}\text { Sand } \\
\text { HWT }\end{array}$ & 6439 & 26 & +24 & 264 & 3751 & -42 \\
\hline $11(56)$ & $\begin{array}{l}610 \mathrm{~mm} \text { PSC } \\
76 \mathrm{~mm} \text { void } D\end{array}$ & $19 \cdot 60$ & $\begin{array}{c}\text { Sand with silt and clay } \\
\text { HWT }\end{array}$ & 3524 & 1 & -48 & 72 & 2100 & -40 \\
\hline $12(62)$ & 610 mm PSC & $58 \cdot 52$ & $\begin{array}{c}\text { Sand and clay } \\
\text { HWT }\end{array}$ & 2893 & 8 & +24 & 80 & 2203 & -24 \\
\hline 14(69) & $\begin{array}{c}406 \mathrm{~mm} \text { PSC } \\
102 \mathrm{~mm} \text { void } D\end{array}$ & $24 \cdot 38$ & $\begin{array}{c}\text { Clay and sand } \\
\text { HWT }\end{array}$ & 2626 & 15 & +48 & 180 & 3204 & +22 \\
\hline $18(73)$ & $\begin{array}{c}610 \mathrm{~mm} \text { PSC } \\
\text { Octagonal }\end{array}$ & $25 \cdot 91$ & $\begin{array}{c}\text { Sand and clay } \\
\text { HWT }\end{array}$ & 4873 & 10 & +24 & 1000 & 3814 & -22 \\
\hline 23(102) & HP $299 \times 79$ & $22 \cdot 86$ & - & 1664 & 1 & +5 & 192 & 2185 & +31 \\
\hline 29(130) & $\begin{array}{c}324 \mathrm{~mm} \times 6 \mathrm{~mm} \\
\text { CEP }\end{array}$ & 24.99 & Silt & 970 & 16 & +24 & 120 & 774 & -20 \\
\hline 33(165) & $\begin{array}{c}324 \mathrm{~mm} \times 13 \mathrm{~mm} \\
\text { CEP }\end{array}$ & $27 \cdot 43$ & $\begin{array}{c}\text { Clay and silt } \\
\text { HWT }\end{array}$ & 2496 & 17 & +12 & 96 & 3115 & +25 \\
\hline 35(169) & $\begin{array}{c}324 \mathrm{~mm} \times 13 \mathrm{~mm} \\
\text { CEP }\end{array}$ & $21 \cdot 00$ & - & 788 & 14 & -24 & 48 & 1504 & +54 \\
\hline 36(170) & $\begin{array}{c}324 \mathrm{~mm} \times 13 \mathrm{~mm} \\
\text { CEP }\end{array}$ & $17 \cdot 00$ & - & 712 & 14 & -24 & 24 & 1148 & +44 \\
\hline
\end{tabular}

CEP, closed-ended pipe; D, diameter; DT, dynamic test; HP, H-pile; HWT, high water table; PSC, prestressed concrete

Pile number: numbers in parentheses are from the FHWA database. Time between SLT and DT: minus or plus means dynamic testing was done before or after SLT, respectively. The time after EOD is shown for dynamic testing. Signal matching: minus or plus in error means under- or over-estimated Capwap results

Calculated capacities for five piles $(12,14,18,29$ and 33) have errors from 20 to $25 \%$. The worst Capwap results were obtained for seven piles $(2,7,10,11,23,35$ and 36). Piles 2, 7, 10 and 11 had underestimated capacities with errors of $-30,-42,-42$ and $-40 \%$, respectively, but piles 23,35 and 36 have overestimated pile capacities with errors of 31,54 and $44 \%$, respectively. Comments of the worst results are presented by Svinkin (2002).

Effects of various factors on the results of HSDPT were analysed. First, the time between compared tests was in the limit of 1-2 d. Second, the time after pile installation affects the rate of pile capacity change. For a short period after EOD, larger discrepancies would be expected. Third, the sequence of tests is important. HSDPT destroyed soil consolidation around the pile, and the soil could not reconsolidate for $1-2 \mathrm{~d}$ for performance of SLT. Perhaps this is the cause of the big discrepancy between compared pile capacities for three piles (11, 35 and 36). Therefore, HSDPT should be conducted after SLT to obtain better results. Fourth, no correlations were found between pile type and computed pile capacities. Fifth, no correlations were found between high blow count and computed pile capacities. Sixth, there are substantial differences between various signalmatching techniques. It is obvious that 'best match' is the preferred procedure in the Capwap signal-matching technique. The described results were obtained with the Capwap program, but similar outputs could be expected from the usage of other signal-matching techniques. Seventh, no correlations were found between pile type and computed pile capacities. Eighth, it is necessary to collect more information to reveal effects of soil conditions on computed results.

Analyses of disagreements between pile capacities determined by dynamic and static tests were performed for specified piles, driving equipment and soil conditions, and it is unknown what differences may be expected at other sites. Unfortunately, such differences are unknown in advance before implementation of static and dynamic tests.

It is necessary to note that a comparison of static and dynamic test results has certain scientific interest for verification of pile capacity determined by HSDPT, but it does not provide answers regarding the capacity of a pile to be able to withstand design loads applied to piles at the specified site. This is a disadvantage of such verification of the pile capacity determined by HSDPT.

\section{Likins and Rausche (2004)}

The authors reviewed the correlation of Capwap results with SLTs presented in the proceedings of the first six stress-wave conferences. The results were summarised in the database of 147 piles included in the paper. Comparative results of dynamic and static tests are shown in Table 2 for the identified 84 piles.

Various failure criteria were used for interpretation of SLT. A comparison of in situ testing provides only a general picture of 
Table 2. Errors in determination of pile capacity by Capwap

\begin{tabular}{lccrc} 
& \multicolumn{2}{c}{ Underestimation } & & \multicolumn{2}{c}{ Overestimation } \\
\cline { 2 - 3 } \cline { 5 - 5 } SLT failure criteria & Number of case histories & Range of errors: \% & Number of case histories & Range of errors: \% \\
\hline Maximum load & 13 & -2 to -14 & 13 & 0 to +29 \\
Failure load & 18 & -2 to -40 & 9 & +2 to +27 \\
Davisson & 29 & -1 to -40 & 27 & 0 to +52 \\
D/10 & 10 & -2 to -17 & 5 & +2 to +30 \\
Chin & 4 & -11 to -33 & - & - \\
Brinch Hansen & 4 & -3 to -14 & 1 & -15 \\
Van der Veen & 1 & -13 & 2 & 0 to +7
\end{tabular}

errors in determination of pile capacity by HSDPT with Capwap. The use of the Davisson criteria yields a range of errors from -1 to $-40 \%$ for underestimation and from 0 to $+52 \%$ for overestimation of pile capacities. It seems that errors below $20 \%$ could be accepted, but higher errors in particular of about $40-52 \%$ are beyond the acceptable limits. Different ranges of errors were obtained for other failure criteria. These analyses were performed without connection with the design pile loads. Obviously, such an approach cannot help in evaluation of the pile capacity in advance of pile testing at other construction sites.

The authors also used other approaches for comparison of static and dynamic results. The database from six stress-wave conferences was combined with the existing database and increased the number of cases to 303. Different combinations of driven piles, cast-in-situ piles, soil conditions, Capwap procedures and times of implementation of static and dynamic tests were used to compare results of Capwap and SLT capacities. A sample of such comparison is shown in Figure 1.

What is the sense of such a mixture of various factors such as piles, soil conditions, pile driving equipment, times after the EOD

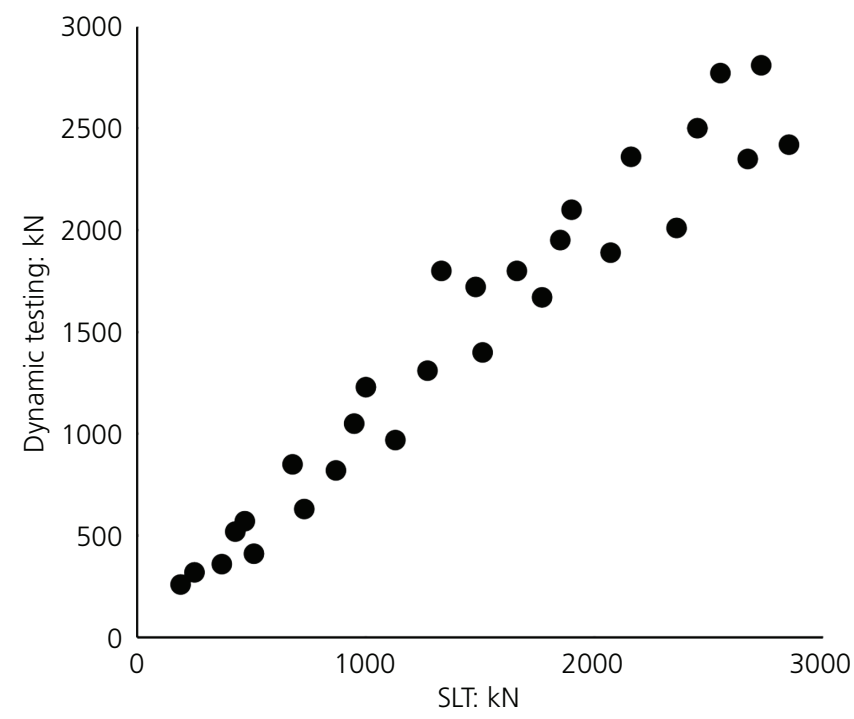

Figure 1. Typical comparison of dynamic and static test results and between compared tests and various time effects on pile capacity taken together to make general conclusions about the applicability of dynamic testing at any construction site? It is necessary to say that there is a very conditional comparative basis for the statistical correlation of various cases with dynamic and static tests. However, the authors believe that they received trustworthy results. It is very dubious because the results of HSDPT with Capwap or another software must be evaluated with SLT for each construction site independently of the exiting statistical correlations between in situ tests.

\section{Rausche et al. (2004)}

The paper analysed the results of dynamic pile testing performed by the Louisiana Department of Transportation and Development between 2001 and 2003. Piles were installed in areas known for developing a large set-up capacity during chosen long waiting periods following pile installation. Therefore, dynamic tests were performed at the EOD, after $24 \mathrm{~h}$, and then again typically $14 \mathrm{~d}$ after pile installation, sometimes after having performed an SLT.

Pile and site information is shown in Table 3. The soil generally consisted of sandy clays, clayey sand and some combinations of clay, sand and silt. The results of static and dynamic tests of ten piles are shown in Table 4. For restrikes 2, the capacity calculated by Capwap was increased between blow counts of 129 blows $/ 0 \cdot 3 \mathrm{~m}$ and 480 blows $/ 0.3 \mathrm{~m}$ by a factor, linearly increasing between $1 \cdot 0$ and $1 \cdot 2$ and then remaining at $1 \cdot 2$.

The outcomes of determination of pile capacity are the following. For restrike 2, there are three piles $(8,9$ and 16) with good results (errors below 20\%), six piles (3a, 4, 10a, 10b, 15c and 16) with overestimated results and an error was not evaluated for pile $10 \mathrm{c}$ because the Capwap result was close to the maximum load at SLT. For restrike 1, there are good results for five piles $(4,8,10 \mathrm{a}, 15 \mathrm{~b}$ and 16), overestimated results for two piles (3a and 9) and no calculated errors for two piles ( $10 \mathrm{~b}$ and $15 \mathrm{c})$. It necessary to mention three piles $(8,9$ and 16) with errors higher than those for restrike 2.

Based on field measurements, the paper suggests the use of $24 \mathrm{~h}$ restrike after the EOD as the best solution for pile capacity determination (capacity prediction in the text is incorrect). This conclusion is opposite to that of Likins and Rausche (2004) and other publications. It seems such an opposite conclusion was 
Table 3. Pile and site information

\begin{tabular}{|c|c|c|c|c|c|c|}
\hline Case number & Pile type & Pile length: $\mathrm{m}$ & Pile penetration: $\mathrm{m}$ & Hammer & Soil shaft & Soil toe \\
\hline $3 a$ & Pipe $24 \times 1 / 2^{\prime \prime}$ & $33 \cdot 5$ & $16 \cdot 2$ & D 36-32 & Sandy clay & Silty sand \\
\hline 4 & PSC24 × 24" & $20 \cdot 7$ & 11.9 & D $36-32$ & Sandy silty clay & Sandy clay \\
\hline 8 & PSC16 × 16" & $23 \cdot 5$ & $9 \cdot 9$ & ICE 60S & Clay, sand, silt & Sand with clay \\
\hline 9 & PSC16 $\times 16^{\prime \prime}$ & $16 \cdot 8$ & $11 \cdot 0$ & ICE 605 & Clay, silty clay & Sandy clay \\
\hline $10 a$ & PSC16 $\times 16^{\prime \prime}$ & $18 \cdot 3$ & $8 \cdot 2$ & ICE 605 & Sandy clay & Clayey sand \\
\hline $10 b$ & PSC16 $\times 16^{\prime \prime}$ & $18 \cdot 3$ & $8 \cdot 2$ & ICE $60 S$ & Sandy clay & Clayey sand \\
\hline $10 c$ & PSC16 $\times 16^{\prime \prime}$ & $18 \cdot 3$ & $8 \cdot 2$ & ICE $60 S$ & Sandy clay & Clayey sand \\
\hline $15 b$ & PSC14 × 14" & $18 \cdot 0$ & $13 \cdot 2$ & ICE $60 \mathrm{~S}$ & Silty clay, sand & Silty clay with sand layers \\
\hline $15 c$ & PSC14 × 14" & $18 \cdot 0$ & $13 \cdot 2$ & ICE $60 \mathrm{~S}$ & Silty clay, sand & Silty clay with sand layers \\
\hline 16 & PSC16 $\times 16^{\prime \prime}$ & $21 \cdot 3$ & $7 \cdot 0$ & ICE $60 S$ & Clay & Clayey fine sand \\
\hline
\end{tabular}

$1^{\prime \prime}=1$ inch $=25 \cdot 4 \mathrm{~mm}$

Table 4. Results of static and dynamic pile tests

\begin{tabular}{|c|c|c|c|c|c|c|c|c|c|}
\hline \multirow[b]{2}{*}{ Case number } & \multirow{2}{*}{$\begin{array}{l}\text { EOD blow count: } \\
\text { blows } / 0.3 \mathrm{~m}\end{array}$} & \multirow{2}{*}{$\begin{array}{l}\text { R2 blow count: } \\
\text { blows } / 0.3 \mathrm{~m}\end{array}$} & \multirow{2}{*}{$\begin{array}{l}\text { Load } \\
\text { test : } k N\end{array}$} & \multicolumn{6}{|c|}{ Capwap } \\
\hline & & & & $\begin{array}{l}\text { EOD } \\
R_{\mathrm{u}}: \mathrm{kN}\end{array}$ & Error: \% & $\begin{array}{c}\text { Restrike } 1^{\mathrm{a}} \\
R_{\mathrm{u}}: \mathrm{kN}\end{array}$ & Error: \% & $\begin{array}{c}\text { Restrike } 2^{\mathrm{b}} \\
R_{\mathrm{u}}: \mathrm{kN}\end{array}$ & Error: \% \\
\hline $3 a$ & 26 & 108 & 1344 & 1335 & -0.7 & 1958 & +46 & 1958 & +46 \\
\hline 4 & 20 & 192 & 3204 & 1420 & -56 & 2959 & -8 & 4050 & +26 \\
\hline 8 & 9 & 100 & 997 & 227 & -77 & 890 & -11 & 912 & -9 \\
\hline 9 & 7 & 200 & 961 & 178 & -81 & 579 & -40 & 781 & -19 \\
\hline $10 a$ & 11 & 204 & $>1202$ & 245 & $>-80$ & 1153 & $>-4$ & 1584 & $<+32$ \\
\hline $10 \mathrm{~b}$ & 19 & 216 & $>1202$ & 441 & $>-63$ & 1224 & - & 1523 & $<+27$ \\
\hline $10 c$ & 7 & 84 & $>1202$ & 223 & $>-81$ & 935 & $>-22$ & 1219 & - \\
\hline $15 b$ & 10 & 60 & 997 & 441 & -56 & 1001 & $+0 \cdot 4$ & 1219 & +22 \\
\hline $15 c$ & 40 & 300 & $>1210$ & 605 & $>-50$ & 1357 & - & 2340 & $<+93$ \\
\hline 16 & 190 & 804 & 2648 & 1420 & -46 & 3066 & +16 & 2296 & -13 \\
\hline
\end{tabular}

$R_{\mathrm{u}}$, ultimate pile capacity

${ }^{a}$ First restrikes were done in $24 \mathrm{~h}$ after pile installation (Rausche et al., 2004)

${ }^{b}$ Adjusted for high blow counts for using cases with excessive blow counts (Rausche et al., 2004)

made under the effects of problems with the Capwap applications at the sites with complicated soil conditions. It is necessary to point out that piles were driven at areas with large set-up capacities. Therefore, a waiting period had to be much longer than $14 \mathrm{~d}$ after EOD, but it was not done at the site.

The authors paid attention to one more important problem of HSDPT. They found variable pile driving conditions when pile capacity determination at restrike often yielded unreliable results because of the variability of hammer energy and soil resistance (set per blow) to pile penetration into the ground. It is possible that the applied software could not properly take into account soil changes in $14 \mathrm{~d}$ after EOD and the variable hammer energy to evaluate properly the pile capacity.

\section{Evaluation of static pile capacity determined by dynamic testing}

There is no general adequacy for dynamic and static tests because of their different natures. For each construction site or even for different parts of a great size construction area, it is necessary to verify the adequacy of both tests.

Determination of the static pile capacity by dynamic testing demonstrates various outcomes. There are numerous cases with good results, a certain number of cases with bad results and some cases with critical outcomes. Therefore, the static pile capacities obtained from dynamic testing must be verified by SLT because there is no other way to determine the accuracy of dynamic pile testing. At least one SLT has to be performed at the site with homogeneous soils for verification of the results of dynamic testing. Performance of more than one SLT would be necessary at sites with heterogeneous and uncertain soils.

Results of dynamic testing have to be compared with the ultimate capacity determined from SLT. However, there are various interpretations of the failure load from SLT. The Davisson offset limit, developed in conjunction with dynamic pile testing of driven piles (Fellenius, 1980), is the most conservative, but this technique has some deficiency for cast-in-place piles (NeSmith and Siegel, 2009). The Chin method and the $D / 10$ criterion yield results up to $40 \%$ greater than the Davisson limit. It is necessary to perform SLT to failure for correct measurement of the ultimate pile capacity, which is not always an easy task.

The major goal of dynamic testing should be determining the bearing capacity of a pile at the time of testing to withstand design loads with the appropriate FS, which equals 2 for verification of pile capacity with SLT. According to Poulos and 
Davis (1980), empirical methods for working loads can be also used for interpretation of SLT. For design and construction goals, it is rather important to prove the pile capability to withstand twice the design load than determine the ultimate pile capacity from SLT. Therefore, the pile capacity determined by dynamic testing should be not less than twice the design load. Such an approach provides only one criterion for assessment of the applicability of dynamic testing for a specified site. If the results of dynamic testing performed for several piles are below the twice design load $(\mathrm{FS}<2)$, the applied signal-matching software cannot be used at the site. The following case histories illustrate this approach.

\section{Good and mixed results}

Chow et al. (1988)

A $356 \times 368 \times 133 \mathrm{~kg} / \mathrm{m}$ H-pile $(\mathrm{HP})$ was driven in weathered granite residual soil to a depth of $29.4 \mathrm{~m}$. The residual soil consisted of silt- and clay-sized particles with the percentage of coarse fractions increasing with depth. The design load of the pile was $1200 \mathrm{kN}$. A static pile capacity was evaluated from dynamic testing by a signal-matching procedure presented by Lee et al. (1988). The test results are shown in Table 5.

The result of dynamic testing is larger than twice the design load of $1200 \mathrm{kN}$. Therefore, the applied software can be accepted for the considered site. The plunging load was $2776 \mathrm{kN}$, and this value also confirmed the application of dynamic testing for verification of the pile capacity at the site.

\section{Fellenius et al. (1992)}

Three piles were $244 \mathrm{~mm}$ dia., closed-toe steel pipe piles of two different wall thicknesses. A design load of $1100 \mathrm{kN}$ was assigned to these piles with cross-sectional areas of 74 and $81 \mathrm{~cm}^{2}$. The soil conditions consisted of about $10 \mathrm{~m}$ of clay fill underlain by about $20 \mathrm{~m}$ of over consolidated silty clay that gradually changed to clayey silt. Piles 245 and 246 were tested dynamically, and pile 247 driven within a $5 \mathrm{~m}$ distance from these piles and to almost the same embedment depth was subjected to SLT. Information about piles and pile tests is shown in Table 6 .

The repeated SLT yielded $2090 \mathrm{kN}$. Static and dynamic tests provided an FS close to 2 . The FS is expected to be higher than 2 in account of the soil set-up in clayey soils available at the site.

\section{Zheng and Ma (1996)}

A bored pile with a diameter of $1000 \mathrm{~mm}$ and a length of $38.6 \mathrm{~m}$ was installed for a multipurpose building. Soil conditions comprised about $4 \mathrm{~m}$ of various fill followed by about $6 \mathrm{~m}$ of mucky silty sand followed by about $14 \mathrm{~m}$ of mucky clay followed by about $8 \mathrm{~m}$ of clay followed by about $3 \mathrm{~m}$ of gravel deposited on intensely weathered bedrock. The design load of the piles was $3800 \mathrm{kN}$, and, consequently, twice the design load was $7600 \mathrm{kN}$. Capwap was used for determination of the static pile capacity from dynamic testing. The test results are shown in Table 7.

The result of the dynamic testing confirmed the applicability of dynamic testing with Capwap at the considered site.

Liu et al. (1992)

For project $\mathrm{T} 1$, a $350 \times 350 \mathrm{~mm}$ reinforced-concrete precast pile was driven at the site with coastal weak soils. A pile toe penetrated strongly weathered bedrock. A restrike was done in $14 \mathrm{~d}$ after EOD. Pile information and the results of static and dynamic testing are shown in Table 8 .

Dynamic testing provided an FS larger than 2.

Table 5. Results of static and dynamic pile tests

\begin{tabular}{|c|c|c|c|c|}
\hline \multirow{2}{*}{ Design loads: kN } & \multicolumn{2}{|c|}{ SLT } & \multicolumn{2}{|c|}{ Dynamic testing } \\
\hline & Plunging load: kN & FS plunging load & Software (Lee et al., 1988): kN & FS software (Lee et al., 1988) \\
\hline 1200 & 2776 & $2 \cdot 31$ & 2650 & $2 \cdot 21$ \\
\hline
\end{tabular}

Table 6. Results of static and dynamic pile tests

\begin{tabular}{|c|c|c|c|c|c|c|c|c|}
\hline \multirow[b]{2}{*}{ Pile number } & \multirow{2}{*}{$\begin{array}{c}\text { Pile } \\
\text { penetration: } \\
\text { m }\end{array}$} & \multirow{2}{*}{$\begin{array}{l}\text { Design } \\
\text { load: } k N\end{array}$} & \multicolumn{3}{|c|}{ Static test } & \multicolumn{3}{|c|}{ Dynamic testing } \\
\hline & & & $\begin{array}{l}\text { Days after } \\
\text { initial driving }\end{array}$ & $\begin{array}{l}\text { Maximum } \\
\text { load: kN }\end{array}$ & $\begin{array}{l}\text { FS maximum } \\
\text { load }\end{array}$ & $\begin{array}{c}\text { Days after initial } \\
\text { driving }\end{array}$ & $\begin{array}{c}\text { Capwap: } \\
\text { kN }\end{array}$ & $\begin{array}{c}\text { FS } \\
\text { Capwap }\end{array}$ \\
\hline 245 & $34 \cdot 1$ & 1100 & & & & 13 & 2060 & 1.87 \\
\hline 246 & 33.5 & 1100 & & & & 26 & 2365 & $2 \cdot 15$ \\
\hline 247 & $33 \cdot 5$ & 1100 & 22 & 2070 & $1 \cdot 88$ & & & \\
\hline 247 & $33 \cdot 5$ & 1100 & & 2090 & 1.90 & & & \\
\hline
\end{tabular}

Table 7. Results of static and dynamic pile tests

\begin{tabular}{lccccc} 
& & & & \multicolumn{2}{c}{ Dynamic testing } \\
\cline { 2 - 4 } Design loads: $k N$ & Maximum load: kN & FS maximum load & & Capwap: kN & FS Capwap \\
\hline 3800 & 7836 & 2.06 & 8733 & 2.30
\end{tabular}


Table 8. Results of static and dynamic pile tests

\begin{tabular}{|c|c|c|c|c|c|c|c|}
\hline \multirow{2}{*}{$\begin{array}{l}\text { Pile } \\
\text { number }\end{array}$} & \multirow{2}{*}{$\begin{array}{c}\text { Pile } \\
\text { length: } \mathrm{m}\end{array}$} & \multirow{2}{*}{$\begin{array}{c}\text { Pile } \\
\text { penetration: } \mathrm{m}\end{array}$} & \multirow{2}{*}{$\begin{array}{l}\text { Design } \\
\text { loads: kN }\end{array}$} & \multicolumn{2}{|c|}{ SLT } & \multicolumn{2}{|c|}{ Dynamic testing } \\
\hline & & & & $\begin{array}{l}\text { Ultimate } \\
\text { load: kN }\end{array}$ & $\begin{array}{l}\text { FS ultimate } \\
\text { load }\end{array}$ & $\begin{array}{c}\text { Case } \\
\text { method: kN }\end{array}$ & $\begin{array}{l}\text { FS case } \\
\text { method }\end{array}$ \\
\hline T1 & 32 & $26 \cdot 8$ & 700 & 2520 & $3 \cdot 60$ & 2440 & $3 \cdot 49$ \\
\hline
\end{tabular}

Beim et al. (1992)

Nine enlarged-base Franki piles were tested at three sites. Soil borings conducted at the first site indicated mostly clay layers with sandy silt appearing after approximately $10 \mathrm{~m}$. One of the soil borings indicated an intermediate layer of sand between 3 and $8 \mathrm{~m}$. At the second site, soil conditions were very similar to those at the first site. Soil conditions at the third site consisted of a top layer of gravel followed by silty clay between 2 and $10 \mathrm{~m}$ followed by calcareous rock. Pile information and the results of pile dynamic testing are shown in Table 9.

Piles 10, 11 and 33 were vibrated-shaft Franki piles. The test piles were internally driven (conventional) Franki piles. It was a small job and SLT was not performed. Therefore, the FS for the results of dynamic pile testing should be $2 \cdot 5$. The results of dynamic testing satisfied this criterion only for piles 1 and 21 , for which the waiting periods were 50 and $43 \mathrm{~d}$, respectively. For the test piles, the FS may increase on account of the soil set-up.

\section{Chapman and Wagstaff (1992)}

Two $350 \times 350 \mathrm{~mm}$ precast concrete precast piles were driven at two different sites. Pile 452.2 was driven to a $23.6 \mathrm{~m}$ penetration at the site where the soil comprised stiff to very stiff clay to over $30 \mathrm{~m}$ depths. Pile 1 was driven to a $38.5 \mathrm{~m}$ penetration at the site where the soil comprised $10 \mathrm{~m}$ of medium dense grading to loose sand followed by $15 \mathrm{~m}$ of soft to firm silty clay followed by
$10-15 \mathrm{~m}$ of firm to stiff clays overlain moderately to slightly weathered basalt. Pile information and the results of static and dynamic testing are shown in Table 10.

Dynamic testing provided an FS larger than 2 for pile $452 \cdot 1$ and less than 2 for pile 1 . However, the latter can increase in account of the soil set-up in clayey soils available at the site.

\section{Cody and Schwanz (1996)}

Two HP $14 \times 73$ piles, P-2 and P-5, were driven at two sites into river alluvium with a maximum thickness of $43 \mathrm{~m}$. The alluvial deposits consisted of layers of medium- to high-plasticity clays, silt and fine sand with clay being the dominant soil type. The pile design load was $979 \mathrm{kN}$, and twice the design pile capacity should be $1958 \mathrm{kN}$. However, this pile capacity was increased to $2109 \mathrm{kN}$ for the pile test programme to account for an additional $5.5 \mathrm{~m}$ of overburden that would eventually be excavated during installation of the production piles. Therefore, the design pile capacity was $1054 \mathrm{kN}$ at the time of testing. The piles were restruck approximately $24 \mathrm{~h}$ after the end of the initial driving. Capwap was used for determination of the static pile capacity from dynamic testing. The test results are shown in Table 11.

FSs equal 1.71 and 1.54 for Capwap, and they are not sufficient for verification of pile capacity at the considered site although SLT confirmed the adequacy of the piles used for the design load.

Table 9. Results of static and dynamic pile tests

\begin{tabular}{|c|c|c|c|c|c|c|}
\hline \multirow{2}{*}{ Pile number } & \multirow{2}{*}{ Pile diameter: $\mathrm{mm}$} & \multirow{2}{*}{ Shaft length: $m$} & \multirow{2}{*}{ Design load: kN } & \multicolumn{3}{|c|}{ Dynamic testing } \\
\hline & & & & Days after pile installation & Capwap: kN & FS Capwap \\
\hline 10 & 600 & $11 \cdot 5$ & 1700 & 14 & 2230 & $1 \cdot 31$ \\
\hline 11 & 600 & $11 \cdot 4$ & 1700 & 15 & 2430 & 1.43 \\
\hline 33 & 520 & $9 \cdot 0$ & 1300 & 7 & 1863 & 1.43 \\
\hline 122 & 520 & $15 \cdot 0$ & 1300 & 13 & 2370 & 1.82 \\
\hline 106 & 520 & $15 \cdot 0$ & 1300 & 14 & 3230 & $2 \cdot 28$ \\
\hline 91 & 600 & $12 \cdot 5$ & 1700 & 16 & 3800 & $2 \cdot 24$ \\
\hline $90 \mathrm{~A}$ & 520 & $15 \cdot 0$ & 1300 & 13 & 2740 & $2 \cdot 11$ \\
\hline 1 & 520 & $12 \cdot 9$ & 1300 & 50 & 5310 & $4 \cdot 08$ \\
\hline 21 & 520 & $11 \cdot 1$ & 1300 & 43 & 4570 & $3 \cdot 52$ \\
\hline
\end{tabular}

Table 10. Results of static and dynamic pile tests

\begin{tabular}{|c|c|c|c|c|c|c|}
\hline \multirow{2}{*}{ Pile number } & \multirow{2}{*}{ Pile penetration: $\mathrm{m}$} & \multirow{2}{*}{ Design loads: kN } & \multicolumn{2}{|c|}{ SLT } & \multicolumn{2}{|c|}{ Dynamic testing } \\
\hline & & & Maximum load: kN & FS maximum load & Capwap: kN & FS Capwap \\
\hline $452 \cdot 1$ & $23 \cdot 6$ & 1800 & 3600 & $2 \cdot 00$ & 4089 & $2 \cdot 27$ \\
\hline 1 & $38 \cdot 5$ & 1700 & 3400 & $2 \cdot 00$ & 3125 & $1 \cdot 83$ \\
\hline
\end{tabular}


Table 11. Results of static and dynamic pile tests

$\begin{array}{lccccccccc}\text { Pile number } & \begin{array}{c}\text { Design } \\ \text { loads: } k \text { N }\end{array} & \begin{array}{c}\text { Days after dynamic } \\ \text { testing }\end{array} & \begin{array}{c}\text { Plunging } \\ \text { load: } k N\end{array} & \begin{array}{c}\text { Maximum } \\ \text { load: kN }\end{array} & \begin{array}{c}\text { FS plunging } \\ \text { load }\end{array} & \begin{array}{c}\text { Days after initial } \\ \text { driving }\end{array} & \begin{array}{c}\text { Capwap: } \\ \text { kN }\end{array} & \begin{array}{c}\text { FS } \\ \text { Capwap }\end{array} \\ \text { P-2 } & 1054 & 7 & 2215 & 2313 & 2 \cdot 10 & & 1 & 1802 & 1.71 \\ \text { P-5 } & 1054 & 10 & 2046 & 2091 & 1.94 & 1 & 1629 & 1.54\end{array}$

However, such results could be expected for dynamic testing as well because dynamic testing, unlike SLT, was conducted in $1 \mathrm{~d}$ after EOD.

\section{Bradshaw and Baxter (2006)}

Static and dynamic tests were performed on 15 piles driven for the Central Artery/Tunnel Project in Boston. Typical soil conditions comprised about $3-5 \mathrm{~m}$ of fill followed by about $3 \mathrm{~m}$ of sand followed by about $20-30 \mathrm{~m}$ of marine clay followed by about $5-15 \mathrm{~m}$ of sand or silt underlain by bedrock. Dynamic tests at the beginning of restrike were conducted $1-7 \mathrm{~d}$ after pile installation with an exception of piles ET2-C2 and ET4-3B, which were dynamically tested during restrike after SLT had been performed. SLTs were carried out on 15 piles approximately 1-12 weeks after installation. Pile information and the results of static and dynamic testing are shown in Table 12.

\section{Bad and critical results}

\section{Matsukida and Kato (1992)}

A $1600 \mathrm{~mm}$ dia. steel tubular pile was driven through very weak silt, improved by sand compaction piles, into the bearing sand layer underneath. The pile was redriven two times in 13 and $20 \mathrm{~d}$ after EOD. Then, the pile was redriven with a follower.
SLT was not performed. However, determination of the static pile capacity by dynamic testing at the first redrive in $13 \mathrm{~d}$ after EOD showed FS $=1.97$. The same result was obtained from the second redriving conducted in $20 \mathrm{~d}$ after EOD. Then, redriving with a follower was performed, and the pile capacity decreased. FS was $1 \cdot 65$. It is doubtful that the soil set-up will provide the required $\mathrm{FS}=2 \cdot 5$. The authors used the case method in addition to TNOWave. However, it would be more beneficial to use another signal-matching software such as Capwap or Simbat for comparison of computed pile capacities. Pile information and the results of dynamic testing are shown in Table 13.

The authors expected that the time effects of soil recovery in the silt layer would generate further pile capacity increase. The purposes of pile monitoring application were satisfied. Nevertheless, the authors paid attention to adequate hammer selection based on reliable driveability analysis and soil investigation.

Liu et al. (1992)

For project T2, two $400 \times 400 \mathrm{~mm}$ reinforced-concrete precast piles were driven at the site with coastal weak soils and the bearing stratum of the pile toe was silty loam. Intervals between

Table 12. Results of static and dynamic pile tests

\begin{tabular}{|c|c|c|c|c|c|c|c|c|}
\hline \multirow{2}{*}{ Pile number } & \multirow{2}{*}{ Pile type } & \multirow{2}{*}{ Embedment depth: $m$} & \multirow{2}{*}{ Design load: $\mathbf{k N}$} & \multirow{2}{*}{ Required FS } & \multicolumn{2}{|l|}{ SLT } & \multicolumn{2}{|c|}{ Dynamic load test } \\
\hline & & & & & Maximum load: kN & Actual FS & Capwap: kN & Actual FS \\
\hline ET2-C2 & $41 \mathrm{~cm} \mathrm{PPC}$ & $47 \cdot 5$ & 1379 & 2.00 & 3122 & $2 \cdot 26$ & 3247 & $2 \cdot 35$ \\
\hline ET4-3B & $41 \mathrm{~cm} \mathrm{PPC}$ & $41 \cdot 1$ & 1379 & 2.00 & 3558 & $2 \cdot 58$ & 3719 & $2 \cdot 70$ \\
\hline 375 & $41 \mathrm{~cm} \mathrm{PPC}$ & $16 \cdot 8$ & 1379 & 2.00 & 3447 & $2 \cdot 50$ & 4759 & 3.45 \\
\hline 923 & $41 \mathrm{~cm} \mathrm{PPC}$ & $32 \cdot 9$ & 1379 & 2.00 & 3447 & $2 \cdot 50$ & 3372 & $2 \cdot 45$ \\
\hline 190 EB SA & $41 \mathrm{~cm} \mathrm{PPC}$ & $46 \cdot 6$ & 1379 & 2.00 & 3781 & $2 \cdot 74$ & 2268 & 1.64 \\
\hline 14 & $41 \mathrm{~cm} \mathrm{PPC}$ & $45 \cdot 4$ & 1379 & $2 \cdot 00$ & 3105 & $2 \cdot 25$ & 2820 & $2 \cdot 04$ \\
\hline $12 \mathrm{~A} 1-1$ & $31 \mathrm{~cm} \mathrm{PPC}$ & $41 \cdot 8$ & 756 & 2.00 & 1512 & $2 \cdot 00$ & 1846 & $2 \cdot 44$ \\
\hline $12 \mathrm{~A} 2-1$ & $31 \mathrm{~cm} \mathrm{PPC}$ & 38.7 & 507 & 2.00 & 1014 & 2.00 & $1454^{a}$ & $2 \cdot 87$ \\
\hline $16 \mathrm{~A} 1-1$ & $41 \mathrm{~cm} \mathrm{PPC}$ & $43 \cdot 3$ & 1245 & $2 \cdot 00$ & 3612 & $2 \cdot 90$ & 1859 & 1.49 \\
\hline 12 & $41 \mathrm{~cm} \mathrm{PPC}$ & $37 \cdot 2$ & 1245 & $2 \cdot 00$ & 3558 & $2 \cdot 86$ & 2015 & 1.62 \\
\hline 3 & $41 \mathrm{~cm}$ pipe & $39 \cdot 6$ & 1583 & $2 \cdot 00$ & 3959 & $2 \cdot 50$ & 2918 & $1 \cdot 84$ \\
\hline 7 & $41 \mathrm{~cm}$ pipe & $38 \cdot 1$ & 1583 & $2 \cdot 00$ & 3167 & $2 \cdot 00$ & 2962 & 1.87 \\
\hline IPE & $32 \mathrm{~cm}$ pipe & $19 \cdot 5$ & 890 & $2 \cdot 25$ & 2384 & $2 \cdot 68$ & $2180^{a}$ & $2 \cdot 45$ \\
\hline IPW & $32 \mathrm{~cm}$ pipe & $22 \cdot 6$ & 890 & 2.25 & $2669^{b}$ & 3.00 & $2758^{a}$ & $3 \cdot 10$ \\
\hline NS-SN & $41 \mathrm{~cm} \mathrm{PPC}$ & $13 \cdot 4$ & 1112 & $2 \cdot 25$ & 2535 & $2 \cdot 28$ & 2793 & $2 \cdot 51$ \\
\hline
\end{tabular}

PPC, prefabricated prestressed concrete

a Blow counts were less than ten blows per $2.5 \mathrm{~cm}$ of pile penetration into the ground

${ }^{b}$ Ultimate capacity

The results of SLT demonstrated that the piles had more capacity than the one required to withstand the design loads. The same outcomes were obtained from dynamic testing of ten piles, but for five piles, FS was less than 2 
Table 13. Results of the dynamic pile tests

\begin{tabular}{lcccccc|} 
Pile number & Pile length: $\mathbf{m}$ & Design loads: $\mathbf{k N}$ & \multicolumn{3}{c}{ Dynamic testing } \\
\cline { 3 - 6 } & & & Redriving days after EOD & TNOWave: kN & FS TNOWave \\
\hline ED3-3 & 78.3 & 13706 & 13 & 27000 & 1.97 \\
ED3-3 & 78.3 & 13706 & 20 & 27000 & 1.97 \\
ED3-3 & 78.3 & 13706 & - & 22600 & 1.65
\end{tabular}

EOD and restrikes of T2-1 and T2-2 were 16 and $12 \mathrm{~d}$, respectively. Pile information and the results of static and dynamic testing are shown in Table 14.

There is a good coincidence between static and dynamic test results. However, static and dynamic tests provided an FS substantially smaller than 2 . The authors mentioned that the ultimate resistance of these piles did not meet the requirements.

\section{Likins et al. (1992)}

Six prestressed concrete piles were analysed. CT1 and CT2 were $450 \mathrm{~mm}$ solid-section piles with penetrations of 20 and $30 \mathrm{~m}$, respectively. CT3 and CT4 were $600 \mathrm{~mm}$ square piles with $260 \mathrm{~mm}$ dia. void and $1 \mathrm{~m}$ solid sections at top and bottom. They had penetrations of 20 and $23 \mathrm{~m}$, respectively. CT5 and CT6 were $900 \mathrm{~mm}$ square piles with $570 \mathrm{~mm}$ dia. void and solid $1 \mathrm{~m}$ at top and bottom. Both piles penetrated 22 and $25 \mathrm{~m}$, respectively. The area was underlain by unconsolidated alluvial deposits of recent age with locally occurring swamp areas. The soil consisted of about $11 \mathrm{~m}$ of silty and sandy deposit (standard penetration test, SPT, $N=0-10$ ) followed by about $4 \mathrm{~m}$ of clay (SPT $N=9-13$ ) followed by about $3 \mathrm{~m}$ of silty sand (SPT $N=35$ ) followed by about $6 \mathrm{~m}$ of clayey sand (SPT $N=31-50 / 100 \mathrm{~mm}$ ) followed by about $2 \mathrm{~m}$ of silty sand (SPT $N=50 / 100 \mathrm{~mm}$ ) underlain by sand. The Tomlinson and Nordlund methods in the computer program SPile were used for static analyses. All piles were tested dynamically and statically. The test results are shown in Table 15.

The authors wrote, 'It is then not surprising that CAPWAP solutions using the classic Smith soil model produced low calculated static resistance values and high Smith damping factors' (Likins et al., 1992: p. 119). Nevertheless, the accuracy of the Capwap results in comparison with the Davisson limit is in approximately the -14 to $+5 \%$ range for piles CT1-CT5 and $-28 \%$ for pile CT6. These are good outcomes of HSDPT for five piles despite the high damping constants in sands at this site. Also, the authors wrote, 'for minimum safety factor of 2.0, failure load should be at least twice the allowable load' (design load) (Likins et al., 1992: p. 119). However, the FSs of static and dynamic tests are substantially smaller than the required value of 2 . Indeed, this site has complicated soil conditions and the ultimate resistance of these piles did not meet the requirements.

Table 14. Results of static and dynamic pile tests

\begin{tabular}{|c|c|c|c|c|c|c|c|}
\hline \multirow[b]{2}{*}{ Pile number } & \multirow{2}{*}{$\begin{array}{c}\text { Pile } \\
\text { length: } \mathrm{m}\end{array}$} & \multirow{2}{*}{$\begin{array}{c}\text { Pile } \\
\text { penetration: } \mathrm{m}\end{array}$} & \multirow{2}{*}{$\begin{array}{c}\text { Design } \\
\text { loads: kN }\end{array}$} & \multicolumn{2}{|c|}{ SLT } & \multicolumn{2}{|c|}{ Dynamic testing } \\
\hline & & & & $\begin{array}{l}\text { Ultimate } \\
\text { load: kN }\end{array}$ & $\begin{array}{c}\text { FS ultimate } \\
\text { load }\end{array}$ & $\begin{array}{c}\text { Case } \\
\text { method: kN }\end{array}$ & $\begin{array}{l}\text { FS case } \\
\text { method }\end{array}$ \\
\hline T2-1 & 34 & $34 \cdot 5$ & 1500 & 2000 & $1 \cdot 33$ & 2100 & $1 \cdot 40$ \\
\hline T2-2 & 34 & $34 \cdot 5$ & 1500 & 2400 & 1.60 & 2330 & 1.55 \\
\hline
\end{tabular}

Table 15. Results of static and dynamic pile tests

\begin{tabular}{|c|c|c|c|c|c|c|c|c|c|}
\hline \multirow[b]{2}{*}{ Pile number } & \multirow[b]{2}{*}{$\begin{array}{l}\text { Number of days } \\
\text { after EOD }\end{array}$} & \multirow[b]{2}{*}{$\begin{array}{l}\text { Design } \\
\text { load: } \mathrm{kN}\end{array}$} & \multirow[b]{2}{*}{$\begin{array}{c}\text { Static } \\
\text { analysis: } \mathrm{kN}\end{array}$} & \multicolumn{4}{|c|}{ Static test } & \multicolumn{2}{|c|}{ Dynamic testing } \\
\hline & & & & $\begin{array}{l}\text { Davisson } \\
\text { limit: kN }\end{array}$ & $\begin{array}{l}\text { Plunging } \\
\text { load: kN }\end{array}$ & $\begin{array}{c}\text { FS } \\
\text { Davisson } \\
\text { limit }\end{array}$ & $\begin{array}{c}\text { FS } \\
\text { plunging } \\
\text { load }\end{array}$ & $\begin{array}{c}\text { Capwap: } \\
\text { kN }\end{array}$ & $\begin{array}{c}\text { FS } \\
\text { Capwap }\end{array}$ \\
\hline \multirow[t]{2}{*}{ CT1 } & 11 & & & & & & & 1702 & 0.67 \\
\hline & 21 & 2530 & 4850 & 1666 & 1915 & 0.66 & 0.76 & & \\
\hline \multirow[t]{2}{*}{ CT2 } & 11 & & & & & & & 2668 & 1.05 \\
\hline & 22 & 2530 & 6720 & 2540 & 2673 & 1.00 & 1.06 & & \\
\hline \multirow[t]{2}{*}{ СТ3 } & 8 & & & & & & & 2615 & 0.68 \\
\hline & 22 & 3820 & 7420 & 2869 & 3118 & 0.75 & $0 \cdot 82$ & & \\
\hline \multirow[t]{2}{*}{ CT4 } & 10 & & & & & & & 3617 & 0.95 \\
\hline & 22 & 3820 & 11160 & 3724 & 4009 & 0.97 & 1.05 & & \\
\hline \multirow[t]{2}{*}{ CT5 } & 6 & & & & & & & 4210 & 0.60 \\
\hline & 20 & 7000 & 12870 & 4900 & 5345 & $0 \cdot 70$ & 0.76 & & \\
\hline \multirow[t]{2}{*}{ CT6 } & 3 & & & & & & & 4994 & 0.71 \\
\hline & 17 & 7000 & 30744 & 6905 & 6905 & 0.99 & 0.99 & & \\
\hline
\end{tabular}




\section{Svinkin (2012)}

Three piles were statically and dynamically tested at a sand site (piles 2 and 4) and a clay site (pile 4). Different signal-matching techniques were applied, and the comparative results are shown in the following section. However, bad and critical results of dynamic pile testing are shown in this section (Table 16).

The errors of $+71 \%$ in clay (Capwap), $+89 \%$ in sand (Simbat) and $+55 \%$ in sand (Statnamic) are bad results. The errors of +341 and $+101 \%$ in sand (TNOWave) and $+116 \%$ in sand (Statnamic) are critical.

\section{The effects of different signal-matching software on computed results}

Chow et al. (1988)

Different signal-matching kinds of software produce diverse results. A $280 \times 280 \mathrm{~mm}$ concrete pile was driven in soft marine clay and socketed into weathered shale. The design load was $800 \mathrm{kN}$. The pile was tested to $1600 \mathrm{kN}$ (twice the design load) using a maintained load test. A static pile capacity was evaluated by Capwap, and a signal-matching procedure was presented by Lee et al. (1988). The test results are shown in Table 17.

Capwap yielded $1373 \mathrm{kN}$ (FS = 1.72), and a second software yielded $1589 \mathrm{kN}(\mathrm{FS}=1.99)$. The Lee et al. (1988) software is the preferred signal-matching technique for this site. Capwap should be applied for other dynamically tested piles for planning about the applicability of this software at the considered site. If the result was the same, Capwap could not be used for verification of the pile capacity at that site. It is necessary to mention that Wong et al. (1992) compared these two signalmatching techniques with a significantly different wave equation model, and for their pile testing, they found that while the total estimated pile capacities are similar, the shaft and toe resistances can differ quite significantly. Obviously, comparable results depend on soil conditions.

\section{Shibata et al. (2000)}

The authors performed a comparative study of static, dynamic and Statnamic tests of three open-ended steel pipe piles in a relatively uniform sandy ground. The test site consisted of fine to gravel sands from the ground surface to a depth of $20 \mathrm{~m}$. A pile layout is a triangle with sides equal to $2 \mathrm{~m}$, and piles were installed in the vertices of the triangle. Three test piles were prepared for dynamic testing (pile D), static load testing (pile S) and soil measurements (pile M). All three piles had the same configuration with steel channels for the protection of the strain gauges, although piles $\mathrm{D}$ and $\mathrm{M}$ were not instrumented with strain gauges. The piles had the following parameters: a length of $13 \mathrm{~m}$, an outer diameter of $400 \mathrm{~mm}$ and a wall thickness of $12 \mathrm{~mm}$. Dynamic and static load tests could be carried out at the same elapsed time after initial pile driving to minimise the influence of the loading history for each pile. The wave-matching analyses were conducted using the Capwap and TNOWave programs. STN was conducted on pile $\mathrm{S} 52 \mathrm{~d}$ after the initial pile driving. The paper provides sufficient data for quantitative assessment of test results, which are shown in Tables 18 and 19.

The piles were only tested, and the design load was not applied in this study. Therefore, the results of dynamic testing and SLT are compared. Capwap provides underestimation of the pile capacity with errors -19 and $-23 \%$ in 6 and $30 \mathrm{~d}$ after the EOD, respectively. TNOWave provides overestimation of pile capacity with an error of $+14 \%$ and yield the exact value of the pile capacity in 6 and $30 \mathrm{~d}$ after the EOD, respectively. The results of STN depend on the applied interpretation method. The errors are 3 and $32 \%$ underestimation by the load transfer method and unloading point method, respectively.

\section{Kikuchi et al. (2000)}

The authors described dynamic and Statnamic tests of three test pipe piles with a length of $50 \mathrm{~m}$ and a diameter of $1.5 \mathrm{~m}$. The wall thickness of the pile was $17 \mathrm{~mm}$ at the head and $15 \mathrm{~mm}$ at the toe. The soil consisted of about $5 \mathrm{~m}$ of backfill material

Table 16. Results of static and dynamic pile tests

\begin{tabular}{|c|c|c|c|c|c|c|c|c|c|c|}
\hline \multirow[b]{2}{*}{ Pile number } & \multirow[b]{2}{*}{ Soil } & \multirow{2}{*}{$\begin{array}{l}\text { SLT Davisson } \\
\text { limit: kN }\end{array}$} & \multicolumn{6}{|c|}{ HSDPT testing } & \multicolumn{2}{|c|}{ STN } \\
\hline & & & $\begin{array}{c}\text { Capwap: } \\
\text { kN }\end{array}$ & Error: \% & $\begin{array}{c}\text { TNOWave: } \\
\text { kN }\end{array}$ & Error: \% & $\begin{array}{l}\text { Simbat: } \\
\text { kN }\end{array}$ & Error: $\%$ & $\begin{array}{c}\text { MLSC or STI: } \\
\text { kN }\end{array}$ & Error: $\%$ \\
\hline 2 & Sand & 1112 & & & 4900 & +341 & 2100 & +89 & 2400 & +116 \\
\hline 4 & Sand & 2892 & & & 5800 & +101 & & & 4490 & +55 \\
\hline 7 & Clay & 2491 & 4250 & +71 & & & & & & \\
\hline
\end{tabular}

MLSC, maximum load on static curve determined by STN; STI, STN interpretation method (Justason and Fellenius, 2001)

Table 17. Results of static and dynamic pile tests

\begin{tabular}{lccccc} 
& & \multicolumn{3}{c}{ Dynamic testing } \\
Design load: kN & SLT maximum load: kN & Capwap & & & Lee et al. (1988) \\
\cline { 3 - 5 } & 1600 & Static pile capacity: $k N$ & FS & Static pile capacity: kN & FS \\
\hline 800 & 1373 & 1.72 & 1589 & 1.99
\end{tabular}


Table 18. Results of static and dynamic pile tests

\begin{tabular}{|c|c|c|c|c|c|c|c|c|c|c|}
\hline \multirow[b]{2}{*}{ Pile number } & \multicolumn{2}{|c|}{ SLT } & \multicolumn{4}{|c|}{ Dynamic testing Capwap } & \multicolumn{4}{|c|}{ Dynamic testing TNOWave } \\
\hline & $\begin{array}{l}6 \mathrm{~d} \text { after } \\
\text { ID: kN }\end{array}$ & $\begin{array}{l}30 \mathrm{~d} \text { after } \\
\text { ID: } \mathrm{kN}\end{array}$ & $\begin{array}{c}6 \mathrm{~d} \text { after } \\
\text { ID: } \mathrm{kN}\end{array}$ & Error: \% & $\begin{array}{l}30 \mathrm{~d} \text { after } \\
\text { ID: kN }\end{array}$ & Error: \% & $\begin{array}{c}6 \mathrm{~d} \text { after } \\
\text { ID: kN }\end{array}$ & Error \% & $\begin{array}{l}30 \mathrm{~d} \text { after } \\
\text { ID: } \mathrm{kN}\end{array}$ & Error: \% \\
\hline$S$ & 1750 & 2320 & & & & & & & & \\
\hline D & & & 1420 & -19 & 1750 & -23 & 2000 & +14 & 2320 & 0 \\
\hline
\end{tabular}

ID, initial driving

Table 19. Results of static and dynamic pile tests

\begin{tabular}{|c|c|c|c|c|c|}
\hline \multirow{2}{*}{ Pile number } & \multirow{2}{*}{$\frac{\text { SLT }}{30 \mathrm{~d} \text { after ID: kN }}$} & \multicolumn{4}{|c|}{ STN } \\
\hline & & LTM: kN & Error: \% & ULPM: kN & Error: \% \\
\hline$S$ & 2320 & 2240 & -3 & 1580 & -32 \\
\hline
\end{tabular}

LTM, load transfer method; ULPM, unloading point method

followed by about $7.5 \mathrm{~m}$ of sandy soils followed by about $32.5 \mathrm{~m}$ silty clay followed by about $5 \mathrm{~m}$ of gravelly sand layer followed by about $23 \mathrm{~m}$ of silty clay underlined by sandy soil. Dynamic and Statnamic tests were performed on three piles. An FS of $2 \cdot 5$ was chosen. The test results are shown in Table 20.

According to available information, the capacities of three piles increased with time after the end of initial driving in account of the soil set-up, which strongly affected the shaft resistance. Obviously, 42-51 d passed before STNs produced much bigger soil set-up and effect on the shaft resistance in comparison with 23-28 d passed before dynamic testing. It is regrettable that dynamic testing was not performed after STNs. Such results could show what test was preferable for the considered site.

\section{Tan and Lin (2014)}

The paper presented a comprehensive full-scale pile load test programme on $457 \mathrm{~mm}$ prestressed concrete piles in Savannah, GA, USA. Four piles were tested. Dynamic tests, STN and SLT were performed. TP1 and TP2 were 25.6 and $22.9 \mathrm{~m}$ long, respectively; TP3 was $29 \cdot 8 \mathrm{~m}$ long (made from two equal segments) and TP5 was $19.8 \mathrm{~m}$ long. The soil consisted of about $1.4 \mathrm{~m}$ of hydraulic fill followed by $10.8 \mathrm{~m}$ of very soft clay followed by about $5.2 \mathrm{~m}$ of medium-dense to dense fine sand followed by $11.6 \mathrm{~m}$ of very stiff sandy clay and silty clay (marl) followed by $3.0 \mathrm{~m}$ of silty fine sand and underlain by limestone. The results of static, dynamic and Statnamic tests are shown in Table 21.
It can be seen that the FS is higher than 2 to consider the downdrag loads from the upper clay layer. For this site, the FS for STN is larger than the one obtained for SLT and calculated by Capwap. Therefore, STN was chosen for the testing of other piles. However, the FS obtained for Capwap results is acceptable as well, and Capwap can also be used for pile testing at that site.

\section{Svinkin (2012)}

The paper compared the pile capacities determined for three bored piles by HSDPT using three different signal-matching techniques and STNs. The results of field pile tests were presented by Briaud et al. (2000). All three piles were planned to be $0.915 \mathrm{~m}$ dia. and varied in length between about 10.7 and $11.7 \mathrm{~m}$. Pile 2 at the sand site was purposely built with defects: mud cake of about $15 \mathrm{~mm}$ thick on the side-wall, a soft bottom and concrete contamination at $5 \cdot 3 \mathrm{~m}$ below the pile head. One more unplanned defect occurred at $5 \mathrm{~m}$ below the pile head and resulted in a $45 \%$ reduction in area. Pile 4 at the sand site was planned as a pile without defects, but during construction, caving of the side-walls created an unplanned bulging defect resulting in a $10 \%$ average increase in diameter between 1.2 and $7.5 \mathrm{~m}$ below the pile head. Pile 7 at the clay site was planned and constructed as a perfect pile.

After SLTs, STNs were conducted in 4-6 d. Then, after STNs, drop weight tests were performed in 1-2 d. SLT 2 for pile 2 was conducted in $2 \mathrm{~d}$ after dynamic testing. Results of static (the result of SLT 2 is shown for pile 2) and dynamic pile tests are shown in Table 22.

Table 20. Results of dynamic pile tests

\begin{tabular}{|c|c|c|c|c|c|c|c|c|c|}
\hline \multirow{2}{*}{ Pile number } & \multirow{2}{*}{ Design load: kN } & \multicolumn{3}{|c|}{ Dynamic testing } & \multicolumn{5}{|c|}{ STN } \\
\hline & & Days after EID & TNOWave kN & FS TNOWave & Days after EID & SMA: kN & FS SMA & ULPM: kN & FS ULPM \\
\hline V-1 & 3500 & 23 & 7174 & 2.05 & 51 & 20357 & $5 \cdot 82$ & 20081 & $5 \cdot 74$ \\
\hline V-2 & 3500 & 25 & 6079 & 1.74 & 49 & 22689 & $6 \cdot 48$ & 23292 & $6 \cdot 65$ \\
\hline$V-3$ & 3500 & 28 & 7507 & $2 \cdot 14$ & 42 & 20682 & $5 \cdot 91$ & 19956 & $5 \cdot 70$ \\
\hline
\end{tabular}

EID, end of initial driving; SMA, signal-matching analysis; ULPM, unloading point method 
Table 21. Results of static and dynamic pile tests

\begin{tabular}{|c|c|c|c|c|c|c|c|c|c|c|}
\hline \multirow[b]{2}{*}{ Pile number } & \multirow{2}{*}{$\begin{array}{c}\text { Design loads: } \\
\text { kN }\end{array}$} & \multicolumn{3}{|c|}{ SLT } & \multicolumn{3}{|c|}{ Dynamic testing } & \multicolumn{3}{|c|}{ STNs } \\
\hline & & $\begin{array}{c}\text { Days after } \\
\text { EID }\end{array}$ & $\begin{array}{l}\text { Ultimate } \\
\text { capacity: kN }\end{array}$ & $\begin{array}{l}\text { FS } \\
\text { SLT }\end{array}$ & $\begin{array}{c}\text { Days after } \\
\text { EID }\end{array}$ & $\begin{array}{c}\text { Capwap: } \\
\text { kN }\end{array}$ & $\begin{array}{c}\text { FS } \\
\text { Capwap }\end{array}$ & $\begin{array}{c}\text { Days after } \\
\text { EID }\end{array}$ & $\begin{array}{l}\text { SUPM: } \\
\text { kN }\end{array}$ & $\begin{array}{l}\text { FS } \\
\text { SUPM }\end{array}$ \\
\hline TP1 & 890 & & & & 4 & 2848 & $3 \cdot 20$ & 6 & 3960 & 4.45 \\
\hline TP2 & 890 & 12 & 3600 & 4.04 & 4 & 2800 & $3 \cdot 15$ & 6 & 3300 & $3 \cdot 71$ \\
\hline TP3 & 890 & & & & 4 & 2857 & $3 \cdot 21$ & 6 & 3810 & $4 \cdot 28$ \\
\hline TP5 & 890 & & & & 4 & 2038 & $2 \cdot 29$ & & & \\
\hline
\end{tabular}

SUPM, segmental unloading point method

Diverse software and STNs produced different pile capacities for the same impacted piles. Capwap yielded good results for piles 2 and 4 and critical results for pile 7. TNOWave yielded good results for pile 7 and critical results for piles 2 and 4. Simbat yielded good results for piles 7 and 4 and critical results for pile 2. STN yielded bad results for pile 7 and critical results for piles 2 and 4. Obviously, Capwap had preference for testing piles at the sand site, but TNOWave, Simbat and Statnamic had preference for pile testing at the clay site.

It is common to consider the results of dynamic methods as conservative. Therefore, the Davisson criterion is used for their evaluation. If the results of dynamic methods are much higher than the $D / 10$ criterion, as shown in Table 22 , these results should be considered as critical.

\section{The energy effects on dynamic pile testing}

\section{Aoki and de Mello (1992)}

The authors studied the energy effects on Capwap results. A concrete pipe pile with a length of $16.8 \mathrm{~m}$ and an outer diameter of $0.6 \mathrm{~m}$ (a wall thickness of $0.1 \mathrm{~m}$ ) was driven by a free-fall hammer with a fallen weight of $51 \mathrm{kN}$. The soil consisted of $0.95 \mathrm{~m}$ of silty sand followed by $0.85 \mathrm{~m}$ of silty clay followed by $1.20 \mathrm{~m}$ of clayey sand followed by $7.70 \mathrm{~m}$ of silty clay followed by $4.25 \mathrm{~m}$ of sandy clay followed by $4.05 \mathrm{~m}$ of clayey silt followed by $2.36 \mathrm{~m}$ of sandy silt. Fallen heights were in the $0 \cdot 2-2 \cdot 6 \mathrm{~m}$ range. Capwap results obtained for various energy levels are shown in Table 23.

It is shown in Table 23 that the height of the fallen mass was increased 13 times, and such enlargement of dynamic loads increased the total pile capacity more than three times. The energy-pile capacity relationship is shown in Figure 2. Obviously, the Capwap results depend on the energy level of the source. These experiments show that pile capacity can be mobilised under different energy levels. Therefore, mobilised energy is a necessary requirement but an insufficient condition. If so, it would be beneficial to know the energy level or the impact value which can provide the HSDPT results of the pile capacity analogous to the SLT.

The authors also showed that the damping and the quake in the Smith model are not constant soil behaviour parameters as generally postulated, but they are significantly dependent on the energy. In

Table 22. Results of static and dynamic tests

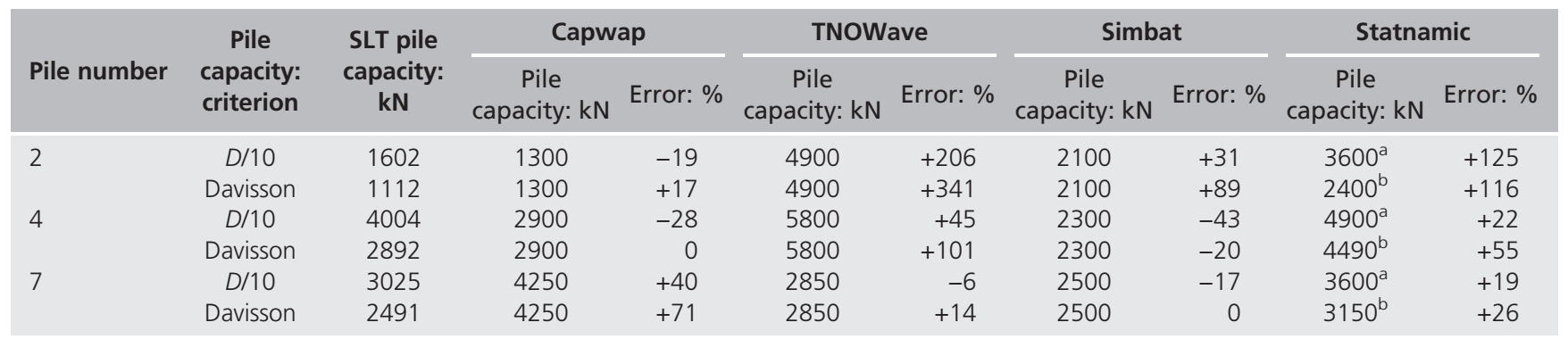

${ }^{\text {a }}$ Maximum load on static curve determined by STN

b Static capacity from the approximate method of STN interpretation (Justason and Fellenius, 2001)

Table 23. Capwap results for various hammer energies

\begin{tabular}{|c|c|c|c|c|c|c|c|c|}
\hline \multirow{2}{*}{ Pile capacity } & \multicolumn{6}{|c|}{ Fall height } & \multirow{2}{*}{$\begin{array}{l}\text { Maximum increase in } \\
\text { fall height: times }\end{array}$} & \multirow{2}{*}{$\begin{array}{l}\text { Maximum increase in } \\
\text { total capacity: times }\end{array}$} \\
\hline & $0.2 \mathrm{~m}$ & $0.5 \mathrm{~m}$ & $1.0 \mathrm{~m}$ & $1.4 \mathrm{~m}$ & $1.7 \mathrm{~m}$ & $2.6 \mathrm{~m}$ & & \\
\hline Toe: kN & 268 & 139 & 140 & 517 & 910 & 1430 & 13 & $5 \cdot 34$ \\
\hline Shaft: kN & 972 & 1801 & 2480 & 2413 & 2420 & 2470 & 13 & $2 \cdot 54$ \\
\hline Total: kN & 1240 & 1940 & 2620 & 2930 & 3330 & 3900 & 13 & $3 \cdot 15$ \\
\hline
\end{tabular}




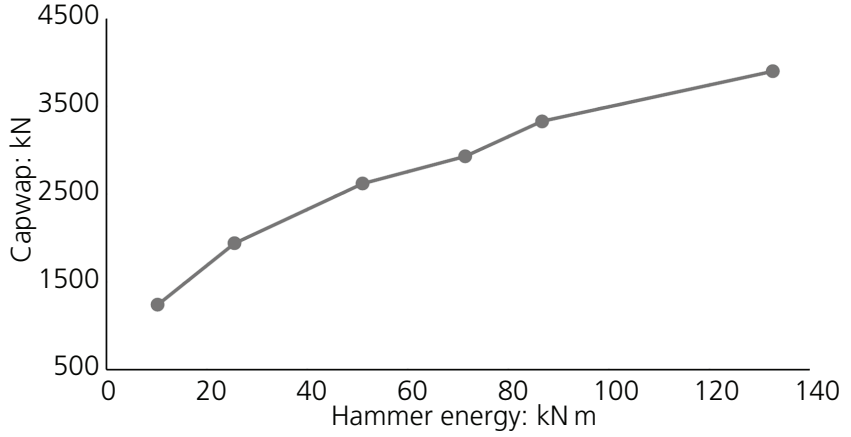

Figure 2. Dependency of Capwap results on the hammer energy in clayey soils

addition, the generalised practice of employing single, constant blowand-set data is clearly insufficient and wrong, and preference points towards more developed models than Smith's one.

\section{Shibata et al. (2000)}

This paper also studied the hammer energy effects on Capwap results. Three steel pipes were driven in sandy soils. Pile and site descriptions are available in the previous section. The pile capacity as a function of the hammer energy is presented in Figure 3. The authors also measured a set per blow in the 3-22 $\mathrm{mm}$ range. It formally corresponds to $100-14$ blows $/ 0 \cdot 3 \mathrm{~m}$. It can be seen that at a certain energy level, enlarging the hammer energy does not increase the pile capacity in sandy soils. Under these energy levels, piles penetrated the ground with $15-14$ blows $/ 0 \cdot 3 \mathrm{~m}$.

The authors recommended experimentally finding out pile driving conditions (energy level and blow count) for receiving the fully mobilised pile capacity prior to actual pile driving.

The authors also showed that the damping and the quake in the Smith model are not constant soil behaviour parameters as generally postulated, but they are significantly dependent on the energy. In addition, the generalised practice of employing single, constant blowand-set data is clearly insufficient and wrong, and preference points towards more developed models than Smith's one.

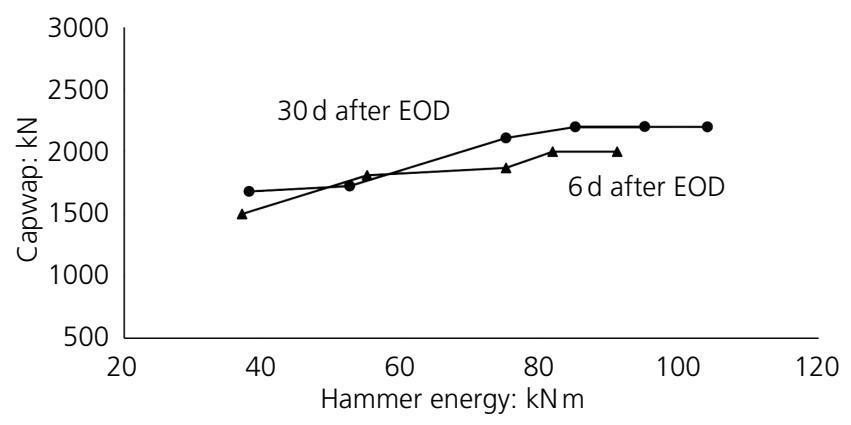

Figure 3. Dependency of Capwap results on the hammer energy in sandy soils
Demonstrated case histories show that pile capacity can be mobilised under different energy levels. Therefore, mobilised energy is a necessary requirement but an insufficient condition. If so, it would be beneficial to know the energy level or the impact value which can provide the HSDPT results of the pile capacity analogous to SLT.

Suitable energy is greatly important for performance of dynamic testing, and it is imperative to know the proper values of impact loads applied to piles during dynamic testing to mobilise the pile capacity similarly to static loads employed in SLT. One possible way for resolving this problem was proposed by Svinkin and Woods (2009). They used a simplified approach to calculation of short-duration impact loads for HSDPT based on the assumption that maximum pile displacements under dynamic and static loads are the same.

\section{Discussion of reasonable determination of pile capacity by dynamic methods}

Dynamic methods are widely used in the pile driving industry. As with any contemporary computing method, these methods include the modelling of the pile-soil system and development of hardware and software which are necessary for measurements at the pile head and analyses. Dynamic methods are beneficial for driveability analysis and pile integrity testing, but the major objective of dynamic pile testing is determination of pile capacity at the time of testing. Dynamic methods have substantial advantages in pile testing because they provide savings in cost and time, which are important in the pile driving industry.

HSDPT and STN are considered as equivalent to SLT in determination of pile capacity despite the different natures of dynamic and static tests. However, the application of dynamic methods has potential obstacles and pitfalls as presented in the overview of the problem. The values of determined pile capacities vary. Good, bad and critical outcomes can be obtained. It was assumed earlier that dynamic methods yield the ultimate pile capacity. Therefore, there is a necessity to compare the results of static and dynamic tests.

There are two approaches to comparison of static and dynamic tests. The first approach is comparison of tests performed for individual piles, and such tests demonstrate a good match of two test results with errors below $20 \%$ in numerous case histories. Nevertheless, there are many other case histories with substantial errors in determination of pile capacity by dynamic methods. In certain cases, it is possible to find explanations of large errors as shown in the overview of the problem. However, in the case studies shown in Table 22, it is difficult to explain the very big differences between static and different dynamic tests.

Capwap yielded good results for piles 2 and 4 at the sand site and critical errors for pile 7 at the clay site $(+71$ and $+40 \%$ for Davisson and $D / 10$ criteria, respectively).

TNOWave yielded good results for pile 7 at the clay site and critical errors for piles 2 and 4 at the sand site $(+341$ and $+206 \%$ 
for Davisson and $D / 10$ criteria, respectively, for pile $2 ;+101$ and $+45 \%$ for Davisson and $D / 10$ criteria, respectively, for pile 4 ).

Simbat yielded good results for pile 7 at the clay site and pile 4 at the sand site and critical errors for pile 2 at the sand site ( +89 and $+31 \%$ for Davisson and $D / 10$ criteria, respectively).

Statnamic yielded bad results for pile 7 at the clay site $(+26$ and $+19 \%$ for Davisson and $D / 10$ criteria, respectively) and critical errors for piles 2 and 4 at the sand site $(+116$ and $+125 \%$ for Davisson and $D / 10$ criteria, respectively, for pile $2 ;+55$ and $+22 \%$ for Davisson and $D / 10$ criteria, respectively, for pile 4).

The mentioned critical errors are not acceptable for verification of the ultimate pile capacity. It is necessary to point out that field measurements and computations of pile capacities were made by companies which originated dynamic methods. Therefore, the performance of the tests was of high quality.

The second approach is analyses of the ratio of pile capacities from restrikes to those from SLT considered for various pile types and lengths, soil conditions and time intervals between comparable tests lumped together. Such an approach is used for statistical evaluation of the adequacy of static and dynamic tests. It is necessary to say that there is a very conditional comparative basis for statistical correlation of various cases with dynamic and static tests because of the big variability of various factors which affect dynamic test results. Furthermore, in real life, it is necessary to know the adequacy of the two tests for each specified construction site with pile installation. It seems that a statistical approach cannot help in evaluation of the adequacy of the two compared tests. Also, it is necessary to underline that the statistical approach does not provide answers regarding the capacity of a pile to be able to withstand design loads applied to piles at the specified site.

A comparison of static and dynamic tests yields beneficial information, but it is not always verification of the pile's ability to withstand design loads. Tables 14 and 15 show good coincidence of the results of dynamic and static tests, but the chosen piles cannot withstand design loads with the appropriate FS. These piles did not meet the requirements.

It is known that there is no panacea method. Each great method has an area of application and certain restrictions. Soil conditions, pile types and driving conditions can affect the application of dynamic methods, and these factors are considered in the modelling of the pile-soil system. It is necessary to point out that hardware and software used in dynamic methods cannot themselves solve engineering problems without engineering analysis and judgement. For validity of new methods, it is necessary to apply the engineering basis to prove the assumptions used in method derivations and find the areas of applications and restrictions of the methods. Nevertheless, it is known that dynamic methods are applied for all types of piles in various soils without restrictions. Obviously, these are not accurate.
In addition to aforementioned problems in the application of dynamic methods, dependency of a computed pile capacity on the hammer energy was found and confirmation was obtained of variable equivalences between diverse dynamic methods which can yield different results for the same piles. For sure, dynamic methods are not adequate compared to SLTs.

Despite these disadvantages, dynamic methods are beneficial for the pile driving industry because they provide savings in the cost and the time of pile testing. Also, dynamic methods can be used for testing of numerous piles at construction sites and in offshore piling. Nevertheless, dynamic methods can yield good, bad and critical results, and such possible outcomes of dynamic pile testing should be considered.

Determination of the ultimate pile capacity is an important and complicated problem in geotechnical engineering. The selection of SLT failure load is somewhat arbitrary. It is known that there is no universal consensus regarding definite preferred criteria, and maybe it is not reasonable to connect pile testing at any construction site with determination of the ultimate pile capacity because the major goal of pile testing at sites is verification of the pile capability to withstand design loads.

Poulos and Davis (1980) described the empirical methods for working loads. One of them requires that the test load be twice the design load and be constant for at least $24 \mathrm{~h}$. This criterion is often used in pile driving practice, and the same criterion should be utilised for evaluation of the results of dynamic methods. Therefore, the pile capacity determined by dynamic testing should be not less than twice the design load. Such an approach provides only one criterion for assessment of the applicability of dynamic testing for a specified site.

For dynamic pile testing, there are no requirements for the applied impact loads or the source energies. There is only the vague criterion of mobilised pile capacity at the time of impact on a pile for receiving good results of dynamic pile testing. Therefore, there are certain restrictions for low and high blow counts during dynamic testing. Obviously, the test results depend on the hammer energy. If the blow count of pile driving is not high, there is a possibility to increase the hammer energy by changing the hammer setting and/or stroke.

It is necessary to test several piles dynamically at a site and one of these piles to test statically. If the results of pile capacity determination are close to twice the design load (conditional difference is $10-20 \%$ ), it is acceptable. If test outcomes are below twice the design load but pile capacities may increase in account of the soil set-up, these are acceptable as well. If the results of such testing are below the twice design load and the soil set-up is not expected or the results are substantially higher than that value, the obtained pile capacity cannot be accepted, and the applied signal-matching software cannot be used at the site. It makes sense to apply another similar software that may yield different 
results. For offshore pile testing, it is problematic to perform SLT. Therefore, it would be beneficial to apply another signal-matching software for verification of the results obtained with the first software.

It is necessary to emphasise that the demonstrated case histories show that pile capacity can be mobilised under different energy levels. Therefore, mobilised energy is a necessary requirement but an insufficient condition. If so, it would be beneficial to know the energy level or the impact value which can trigger dynamic pile settlement equal or similar to static pile settlement from SLT.

\section{Conclusion}

Driven piles are the basis of reliable deep foundations broadly used for various types of buildings and structures. Determination of the ultimate pile capacity is important for correct rational design of pile foundations. Therefore, SLTs are conducted to ascertain correct results of static analyses. Because SLTs are expensive and time-consuming procedures, dynamic methods have become a popular technique for evaluation of the ultimate pile capacity.

Dynamic and static pile tests have different natures of applied forces and responses of pile-soil systems, and dynamic pile testing has some problems and pitfalls. The results of dynamic methods strongly depend on the hammer energy and soil conditions. Nevertheless, it is known that dynamic methods are applied for all types of piles in various soils without restrictions. There are no energy requirements or special guidelines for the application of dynamic methods except vague conditions of mobilised pile capacity. Dynamic methods can yield good, bad and critical results. Therefore, it is imperative to ascertain the results of dynamic methods by SLT.

A comparison of static and dynamic tests yields beneficial information and shows which dynamic testing results can be used. However, such analyses do not always verify the pile ability to withstand design loads. There are examples of good coincidence of the results of both tests, but the chosen piles cannot withstand the design loads with the appropriate FS, and therefore, the chosen piles are not adequate to the design loads.

Notwithstanding these disadvantages, dynamic methods are beneficial for the pile driving industry because they provide savings in the cost and the time of pile testing. In addition, dynamic methods are irreplaceable tools for testing of numerous piles at construction sites and in offshore piling. Nevertheless, it is necessary to distinguish good results of dynamic testing from bad and critical ones.

Determination of the ultimate pile capacity is a significant enigma in geotechnical engineering. However, it is not reasonable to connect pile testing at any construction site with determination of the ultimate pile capacity because the major goal of pile testing at construction sites is verification of the pile capability to withstand design loads.
For several piles dynamically tested at a site, the obtained pile capacities should be compared with the design load multiplied by the required FS. If these values are close, pile testing results are acceptable. Also, it is necessary to consider the possible set-up at the site. Dynamic test results are not acceptable when they are substantially lower or higher than the chosen criterion. It would be helpful to use another signal-matching technique if the first applied software yields unsatisfactory results. This approach provides only one criterion for assessment of the applicability of dynamic testing at a specified site and eliminates requirements of mobilised pile capacity.

Dynamic methods provide a sensible and beneficial approach to verification of the pile capacity necessary for withstanding design loads applied to piles. However, these are not a panacea, but only one more approach to solving the problem. It is necessary to consider dynamic methods objectively and do not expect more than what they can bring in determination of pile capacity.

\section{REFERENCES}

Aoki N and de Mello VFB (1992) Dynamic loading test curves. In Application of Stress-Wave Theory to Piles (Barends FBJ (ed.)). Balkema, Rotterdam, the Netherlands, pp. 525-530.

Beim JW, Paraiso SC and Beim GK (1992) Dynamic testing of enlarged base Franki piles. In Application of Stress-Wave Theory to Piles (Barends FBJ (ed.)). Balkema, Rotterdam, the Netherlands, pp. 227-229.

Bradshaw AS and Baxter CDP (2006) Design and Construction of Driven Pile Foundations - Lessons Learned on the Central Artery/Tunnel Project. Federal Highway Administration, US Department of Transportation, Washington, DC, USA, Publication No. FHWA-HRT-05-159.

Briaud JL, Ballouz M and Nasr G (2000) Static capacity prediction by dynamic methods for three bored piles. Journal of Geotechnical and Geoenvironmental Engineering 126(7): 640-649, https://doi.org/abs/ 10.1061/(ASCE)1090-0241(2000)126:7(640).

Chapman GA and Wagstaff JP (1992) Prediction of pile performance using dynamic testing. In Application of Stress-Wave Theory to Piles (Barends FBJ (ed.)). Balkema, Rotterdam, the Netherlands, pp. 537-543.

Chow YK, Radhakrishman KY, Karunaratne GP and Lee SL (1988) Estimation of pile capacity from stress-wave measurements. In Proceedings of the 3rd International Conference on the Application of Stress-wave Theory to Piles (Fellenius BH (ed.)). BiTech Publishers, Ottawa, ON, Canada, pp. 626-634.

Cody WK and Schwanz NT (1996) Compression and uplift capacity of driven piles. Proceedings of the 5th International Conference on the Application of Stress-wave Theory to Piles, Orlando, FL, USA, pp. 350-366.

Fellenius BH (1980) The analysis of results from routine pile load test. Ground Engineering 13(6): 19-31.

Fellenius BH, Edde RD and Beriault LL (1992) Dynamic and static testing for pile capacity in a fine-grained soil. In Application of Stress-Wave Theory to Piles (Barends FBJ (ed.)). Balkema, Rotterdam, the Netherlands, pp. 401-408.

Goble GG and Rausche F (1970) Pile load test by impact driving Highway Research Record 333: 123-129.

Justason M and Fellenius BH (2001) Discussion of 'Static capacity prediction by dynamic methods for three bored piles' by Briaud J-L, Ballouz M and Nasr G. Journal of Geotechnical and Geoenvironmental Engineering 127(12): 1081-1084, https://doi.org/ 10.1061/(ASCE)1090-0241(2001)127:12(1078).

Kikuchi Y, Nishimura S and Tatsuta M (2000) Statnamic and dynamic load test for large diameter steel piles supported by a thin bearing layer at 
Nagoya port in Japan. Proceedings of the 6th International Conference on the Application of Stress-wave Theory to Piles, São Paulo, Brazil, pp. 599-607.

Lambe TW (1973) Predictions in soil engineering. Géotechnique 23(2): 151-202, https://doi.org/10.1680/geot.1973.23.2.151

Lee SL, Chow YK, Karunaratne GP and Wong KY (1988) Rational wave equation model for pile driving analysis. Journal of Geotechnical Engineering 114(3): 306-325, https://doi.org/10.1061/(ASCE)07339410(1988)114:3(306).

Likins G and Rausche F (2004) Correlation of CAPWAP with static load test. Proceedings of the Seventh International Conference on the Application of Stress Wave Theory to Piles: the Millennium Challenge, Petaling Jaya, Malaysia, pp. 153-165.

Likins G, DiMaggio J, Rausche F and Teferra W (1992) A solution for high damping constants in sands. In Application of Stress-Wave Theory to Piles (Barends FBJ (ed.)). Balkema, Rotterdam, the Netherlands, pp. 117-120.

Likins GE, Rausche F, Thendean G and Svinkin M (1996) CAPWAP correlation studies. Proceedings of the 5th International Conference on the Application of Stress-wave Theory to Piles, Orlando, FL, USA, pp. 447-464.

Liu C, Lin Q and Hang Z (1992) The application of PDA on weak soil in Fujian China. Proceedings of the 5th International Conference on the Application of Stress-wave Theory to Piles, Orlando, FL, USA, pp. 279-283.

Matsukida M and Kato K (1992) Dynamic pile monitoring on the Manmade Island in Trans Tokyo Bay. Proceedings of the 5th International Conference on the Application of Stress-wave Theory to Piles, Orlando, FL USA, pp. 285-292.

Middendorp P (1987) Numerical Model for TNO-WAVE. Instituut TNO voor Bouwmaterialen en Bouwconstructies, Delft, the Netherlands, TNO-IBBC, Report B1-86-75, pp. 6-21.

NeSmith WM and Siegel TC (2009) Shortcomings of the Davisson offset limit applied to axial compressive load test on cast-in-place piles In Contemporary Topics in Deep Foundations (Iskander M, Laefer DF and Hussein MH (eds)). American Society of Civil Engineers, Reston, VA, USA, GSP 185, pp. 568-574.

Paquet J (1988) Checking bearing capacity of dynamic loading - choice of a methodology. In Proceedings of the Third International Conference on the Application of Stress-wave Theory to Piles (Fellenius BH (ed.)). BiTech Publishers, Ottawa, ON, Canada, pp. 383-398.

Poulos HG and Davis EH (1980) Pile Foundation Analysis and Design. Wiley, New York, NY, USA.

Rausche F, Goble GG and Likins G (1985) Dynamic determination of pile capacity. Journal of Geotechnical Engineering 111(3): 367-383, https://doi.org/10.1061/(ASCE)0733-9410(1985)111:3(367).
Rausche F, Robinson B and Likins G (2004) On the prediction of long term pile capacity from end-of-driving information. In Current Practice and Future Trends in Deep Foundations (DiMaggio JA and Hussein MH (eds)). American Society of Civil Engineers, Reston, VA, USA, GSP 125, pp. 77-95.

Shibata A, Kawabata N, Wakiya, Y et al. (2000) A comparative study of static, dynamic and statnamic load tests of steel pipe piles driven in sand. Proceedings of the Sixth International Conference on the Application of Stress-wave Theory to Piles, São Paulo, Brazil, pp. $583-590$

Svinkin MR (2002) Engineering judgement in determination of pile capacity by dynamic methods. In Deep Foundations 2002: an International Perspective on Theory, Design, Construction, and Performance (O’Neill MW and Townsend FC (eds)). American Society of Civil Engineers, Reston, VA, USA, GSP 116, pp. 898-914.

Svinkin MR (2004) Some uncertainties in high-strain dynamic pile testing. In Geotechnical Engineering for Transportation Projects (Yegian MK and Kavazanjian E (eds)). American Society of Civil Engineers, Reston, VA, USA, GSP 126, pp. 705-714.

Svinkin MR (2010) High-strain dynamic pile testing - problems and pitfalls. Journal of Performance of Constructed Facilities 24(2): 99, https://doi.org/10.1061/(ASCE)CF.1943-5509.0000105.

Svinkin MR (2012) Engineering evaluation of static pile capacity by dynamic methods. In Proceedings of $9^{\text {th }}$ International Conference on Testing and Design Methods for Deep Foundations: IS-Kanazawa 2012 (Matsumoto T (ed.)). Kanazawa University, Kanazawa, Japan, pp. $179-186$

Svinkin MR and Woods RD (2009) Dynamic loads for high-strain dynamic pile. In Proceedings of 17th International Conference on Soil Mechanics and Foundation Engineering (Hamza M, Shahien M and El-Mossallamy Y (eds)). IOS Press, Amsterdam, the Netherlands, pp. 1259-1262.

Tan $Y$ and Lin G (2014) Comprehensive load test on prestressed concrete piles in alluvial clays and marl in Savannah, Georgia. Journal of Performance of Constructed Facilities 28(1): 178-190, https://doi.org/ 10.1061/(ASCE)CF.1943-5509.0000305.

Wong KY, Wagstaff JP and Klingberg DJ (1992) Variations in resistance distribution obtained from stress wave analysis. In Application of Stress-Wave Theory to Piles (Barends FBJ (ed.)). Balkema, Rotterdam, the Netherlands, pp. 671-677.

Zheng YM and Ma C (1996) Application of PDA dynamic-testing method to large-diameter bored piles. Proceedings of the 5th International Conference on the Application of Stress-wave Theory to Piles, Orlando, FL, USA, pp. 1159-1171.

\section{How can you contribute?}

To discuss this paper, please submit up to 500 words to the editor at journals@ice.org.uk. Your contribution will be forwarded to the author(s) for a reply and, if considered appropriate by the editorial board, it will be published as a discussion in a future issue of the journal. 